\title{
The Differences in the Interactive Modification of Interaction between Target Groups and Personnel Management Tools
}

\author{
Tanja Gorcheva**
}

The harmonisation of Bulgarian and foreign entrepreneurs' concepts for personnel management is part of Bulgaria's process of transition to free market economy. On the one hand this is possible provided that Bulgarian entrepreneurs get familiar with the practices and experience of their European counterparts. On the other hand foreign investors could be more successfully attracted if they are motivated enough to actively do business in Bulgaria. The research focuses on the differences in policy modelling of the PM target groups and PM instruments in the 17 Bulgarian, 17 German enterprises and 7 JointVentures operating in the markedly dynamic business environment of Bulgarian economy.

Die Annäherung von bulgarischen und ausländischen Unternehmerkonzepten für das Personalmanagement ist Teil des Transformationsprozesses in Bulgarien in eine freie Marktwirtschaft. Auf der einen Seite ist das möglich, vorausgesetzt dass Bulgariens Unternehmer sich mit den Praktiken und der Erfahrung ihrer europäischen Kollegen vertraut machen. Auf der anderen Seite könnten ausländische Investoren erfolgreicher angezogen werden, wenn sie motiviert genug wären, aktiv in Bulgarien tätig zu werden. Die Studie konzentriert sich auf die Unterschiede in den Methoden bezüglich der Zielgruppen und Intrumente des Personalmanagements in 17 bulgarischen, 17 deutschen Unternehmen und 7 Joint-Ventures, die in der marktdynamischen Umgebung der bulgarischen Wirtschaft operieren.

Keywords: Personal Management, Transition Period, Comparative Analysis, Target groups, PM-Tools.

\footnotetext{
Manuscript received: 15.07.04, accepted: 29.11 .04 (3 revisions)

** Tanja Gorcheva, Associated Professor, Tsenov Academy of Economics, Svishtov, Bulgaria. Main research interests: International management, international business, European integration. Corresponding address: Gorcheva@uni-svishtov.bg
} 


\section{Human Resource Management - a key factor of enterprise transformation in the period of transition to free market economy}

The liberalisation of CEE countries' economies led to the liberalisation of capital transfers. Considering the distribution of goods, the comparatively cheap labour and the qualified specialists the CEE countries still have some attractive advantages. At the same time the fierce competition forcing the $\mathrm{EU}$ manufacturers to lower their production costs and optimise their logistics has limited the business opportunities in these countries. That is the reason why the inflow of investments into the CEE countries is constantly growing. It is also the result of the internationalisation processes that affect both the EU and the CEE countries. Bulgaria is not an exception in this respect. The problems related to the restructuring and optimisation of Bulgarian enterprises are being solved by comparing them to the foreign entrepreneurs doing business in Bulgaria. Hence the object of the present research paper is to investigate the changes occurring in personnel management concepts. The harmonisation of Bulgarian and foreign entrepreneurs' concepts for personnel management is part of Bulgaria's process of transition to free market economy. On the one hand this is possible provided that Bulgarian entrepreneurs get familiar with the practices and experience of their European counterparts. On the other hand foreign investors could be more successfully attracted if they are motivated enough to actively do business in Bulgaria. Obviously German investors have sound reasons to invest in our economy because for the last few years the number of German investors and the volume of their investments are steadily growing.

The survey focuses on three main groups of enterprises active in Bulgaria - a country included in the group of countries with economies in transition:

- Joint Ventures;

- $100 \%$ subsidiaries of German corporations;

- comparable in their size and scope of activities Bulgarian enterprises.

Therefore the research had the following aims:

- To define the general characteristics of the economic and political environment of the above target groups of enterprises and to identify the factors influencing their corporate policies related to personnel management;

- To define the differences and similarities of the implementation of various personnel management tools by the three groups of enterprises.

The problems, thus defined, suggest that the liberalisation of CEE countries' national economies and the transformation processes undertaken by them lead not only to quantitative changes related to the restructuring of their economies (growth of private sector, increase of the volume of foreign direct investments, decrease of inflation rates, liberalisation of prices, etc.) but also, and above all, to 
qualitative changes in the form of increased efficiency and functionality of their economic structures and overall improvement of their competitiveness.

\section{Theoretical and methodological constructs comprising the comparative analysis model}

The theoretical background of the research focuses on the relation "production factor-employment, which makes us consider the personnel an important production factor in the reproduction chain. This factor is essential for the success of a company. In this respect we must not forget that the distinction between the managerial and the executive functions results from the division of labor (Holtbrügge/Sulus 1992; Damyanov, A./G.Zaharieva, 1999). Therefore we must note that the significance of the personnel policy, which is not the act of taking a single decision regarding the employment but a process of taking series of decisions related to the personnel contribution to the success of the company.

The theories based on the idea of "incentives-achievements" in the working process postulate that the PM-policy is based on the reflection of the working action and working results regarding the usefulness effect. That's why we will build our policy model of PM on the grounds of this idea.

In the process of modeling we will also take into consideration the theoretical point of view that the PM is building strategies, which have determining importance not only for the manager's actions but also for the employees (Peters/Waterman, 1984; Schuster, 1986; Stefanov, W., 1991). The cultural and national differences are very important for the problems in the field of PM. The influence of these factors can be viewed in two trends - the first one is the connection "environment- PM policy" and the second one is the style of managing including the priority of using the policy tools. In this respect in is clear, that the entrepreneurial culture has an importance of a determinant factor (Hentze, 1989; Holtbrügge, 1992; Bojadziew, D. 1993). Because of this the main object of analyses becomes not simply the work organization in traditional meaning, but also the distribution of competence including the interactive communication between the managers and personal in the multicultural enterprises.

Another significant moment in the research methodology is the development of the PM-policy from the point of view of the tools used for it. In respect we would like to emphasize on the need for harmonization of the tools used and the results achieved. We must not forget that the PM focuses not only on economic targets, but also on sociological and psychological goals.

The implementation of a complex approach (combining economic, social and psychological research methods) in the field of personnel management emphasizes the holistic characteristics of this scientific field. This approach enables us to trace the interrelations between the personality, productivity (the person seen as a factor of production) and management skills of personnel. This 
is why the research model was based on three main analytical aspects: environmental conditions, personnel management (PM) tools and PM target groups (Figure 1). These three analytical aspects form the methodological basis of the research.

The database of the comparative analyses comprises of the information obtained from questionnaires and interviews with managers from the target group enterprises -17 German and 17 Bulgarian enterprises as well as 7 joint-ventures (Table 1.) ${ }^{1}$. The questionnaires were filled and the interviews were held in 2001 and 2003.

Table 1. Survey sample - number of target-group enterprises

\begin{tabular}{|l|c|c|c|}
\hline $\begin{array}{l}\text { Business activity } \\
\text { Economic sector }\end{array}$ & $\begin{array}{l}\text { number of 100\% } \\
\text { German } \\
\text { companies }\end{array}$ & $\begin{array}{l}\text { number of } \\
\text { joint-ventures }\end{array}$ & $\begin{array}{l}\text { Number of Bulgarian } \\
\text { companies }\end{array}$ \\
\hline Banking and insurance & 1 & 1 & 2 \\
\hline Building construction materials & 2 & - & 2 \\
\hline $\begin{array}{l}\text { Civil engineering and building } \\
\text { construction }\end{array}$ & 1 & - & 1 \\
\hline Food-processing industry & 1 & 1 & 1 \\
\hline Trade and distribution* & 1 & 1 & 3 \\
\hline Electrical engineering & 4 & 1 & 2 \\
\hline Clothing industry & 1 & - & 1 \\
\hline Broadcasting and publishing & 1 & 1 & 3 \\
\hline Transportation and logistics* & 1 & 1 & 1 \\
\hline Tourism & 2 & 1 & \\
\hline
\end{tabular}

Data provided by the Foreign Investment Agency. (Source: www.bfia.org)

* Enterprises founded as Joint Ventures and later transformed into 100\% German companies.

The selection of target group enterprises was based on the following criteria:

- enterprise size (number of employees);

- comparability of their business activities (industry);

- comparability of their corporate structure (absence of network structures).

1 The number of German enterprises was determined on the grounds of a selection based on the "continuity of operation in Bulgarian business environment" criterion and the assumption that 17 enterprises operated throughout the whole period in Bulgaria. The selection of Bulgarian enterprises results from the reduction of the initial questionnaire, where initially their number was 34. 
The comparative analyses follows the aims set in the theoretical construct of the research model and every analytical field and segment of the model is followed by comments and conclusions.

Fig. 1 .

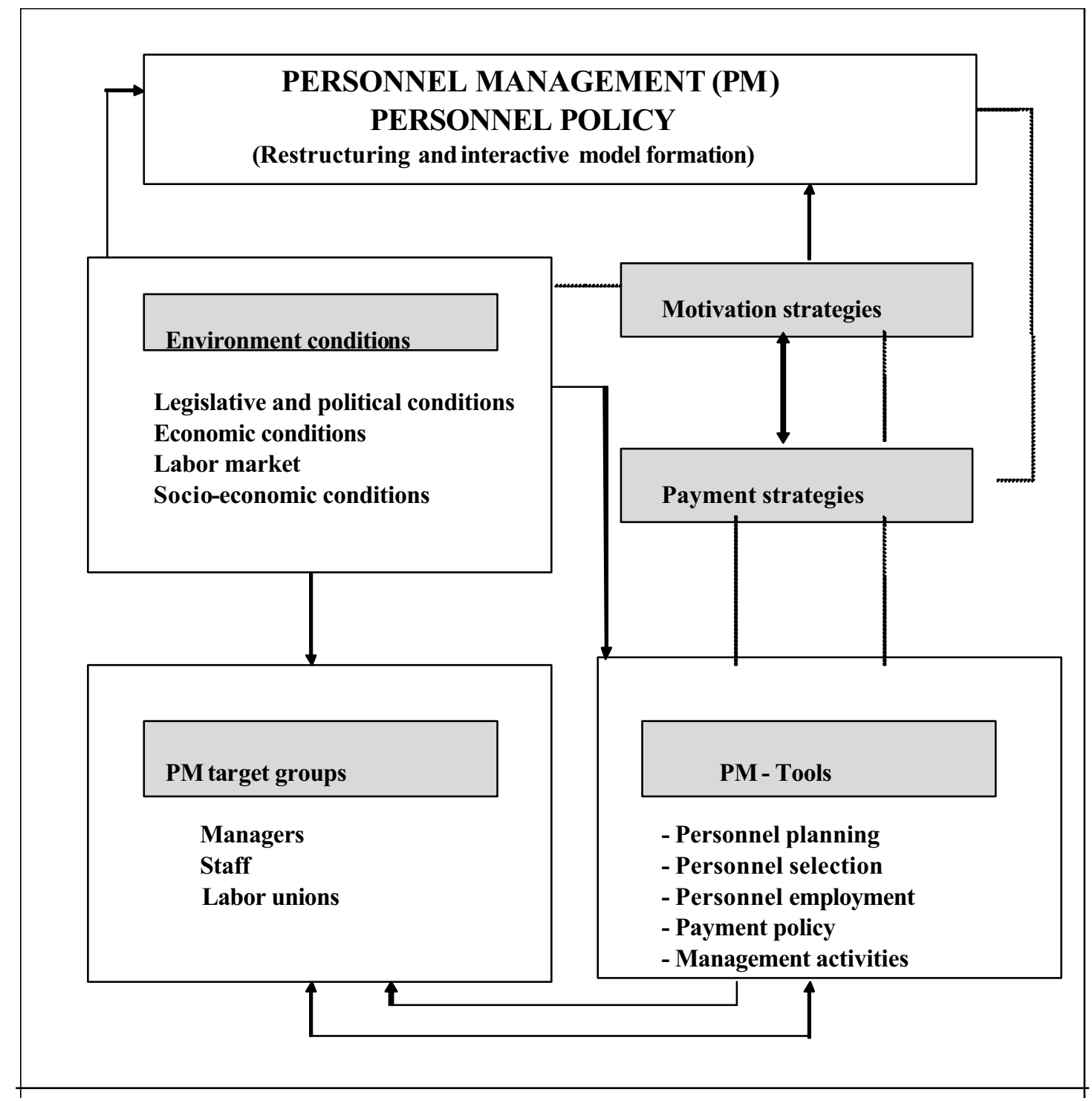

\section{Similarities and differences in personnel management concepts - a comparative analysis}

\subsection{Specifications of the economic environment of the enterprises in Bulgaria}

The intensity of entrepreneurs' business activities undoubtedly depends on the political, economic and social conditions of their environment. These conditions not only influence the activities of the real businesses but also determine the relations between the separate enterprises and the environment as well as the 
partnership or rivalry among the economic entities. The processes of transformation and restructuring in the CEE countries led to the formation of a dynamic and often controversial business environment. Environment's dynamics is determined to a large extent by the degree of success of the economic and political reforms implemented in those countries. The analysis of target enterprises' business environment was performed in the following directions: political and legislative norms, economic conditions and regulations, socioeconomic conditions, labour market.

The ongoing privatisation processes have improved in recent years the political and legislative regulations, which define the business environment in the country. The rate of implementation of the reforms in Bulgaria is not comparable to that of the Vishegrad countries but is more stable and the changes are irreversible. The changes in the constitutional and administrative legislation as well as the changes of labour codes and socio-economic legislation and their actualisation with regard of the free market principles were the priorities in the field of out legal reform.

In Bulgaria like in the other CEE countries the labour relations are regulated within a legal framework of internal negotiations defining the specific labour conditions (UNECE 1990). These negotiations are carried out between the employers and representatives of the labour unions and result in a collective labour contract providing for the remuneration levels, bonuses, working shifts and recesses, health and safety conditions, internal corporate options for re-qualification, disciplinary penalties and the procedures of their implementation, the terms and conditions for the use of the corporate recreation and rehabilitation facilities ${ }^{2}$. The individual labour contracts offered by the enterprises to their employees are based on the collective labour contract.

The analysis of the economic conditions was based on the key indices reflecting the dynamics of the development of our national economy. Such key indices are the production structure, the economic growth, characteristics of the foreigntrade relations and the inflation rates. Bulgaria's production structure ${ }^{3}$ is dominated by the services sector, which accounts for $49 \%$ of the country's gross domestic product. Its share will keep growing owing to the growing demand in this sector. According to the National Statistics Institute Bulgaria's average annual rate of economic growth for the last five years has been $3.5 \%$. Despite the wars in Kosovo (1997 - 1999) and in Serbia (2000), which affected Bulgaria's foreign-trade relations, the economic reforms in the country were gradually carried out. In terms of GDP growth Bulgaria has achieved a marked success compared to the other CEE countries in the region, but compared to the

2 Das Arbeitsgesetzbuch, Dokument Nr.VII.1.1990; Verordnung des Ministerrates Nr.49/1991.

3 Quelle der Angaben: Bulgarische National Bank, Berichte, Periode 1999-2002. 
Vishegrad countries economic growth is still slow although there are some indications of its progress.

The analysis of the labour market shows that the slow implementation of reforms and the stagnation of the economy have resulted in the increase of the unemployment. The official statistics is not entirely objective because it does not take into account the hidden unemployment as well as the "grey economy" employment (UNECE 2000).

Bulgaria's foreign trade relations develop under the influence of its future accession to the EU, which, together with the process of privatisation, has encouraged the foreign investors to enter the country's markets and economy. Germany is one of Bulgaria's main foreign partners both in import and export terms. Germany's import to Bulgaria accounts for $15 \%$ of the total import, which makes that country the second-largest importer after Russia, because of the strong dependence of Bulgaria on Russian imports of fuels and raw materials. Bulgaria's export to Germany amounts to $10 \%$ of its total volume of exports to the EU. (F.A.Z.-Institut 2000/2001). Germany is also one of Bulgaria's leading partners in the field of foreign investments.

On the grounds of the above data and comments on Bulgaria's socio-economic development (which shapes the environment for development of personnel management concepts) we may conclude that: for the period $1998-2003$ Bulgaria's business environment was relatively attractive for the foreign investors. Thus they transfer to Bulgaria their expertise and experience, which are then copied and acquired Bulgarian entrepreneurs operating in the same sectors of the economy. Simultaneously foreign entrepreneurs adapt to the characteristics of our economy, to our traditions and the legislative framework of labour relations in Bulgaria.

\subsection{Research on the interdependence of PM target groups and PM tools}

The research on the interdependence of the two analytical fields (PM target groups and PM tools) was based on the following working theses:

- The formation of PM policies of the German enterprises operating in Bulgaria depends on the specific features of the economic and political environment in the country. Hence no significant differences in the interdependence of PM target groups and PM tools between the Bulgarian and the German enterprises were found;

- The joint venture is a transitional form in the process of formation of personnel policy and adaptation of the German model of to the Bulgarian environment.

Personnel management is a bilateral process in which the managers defend the interests of the owners, which are related to the overall management of the enterprise and the achievement of specific financial goals (Hristova 1996). At the 
same time they should observe the interests of the employees, which are provided for by the labour legislation. This discrepancy causes certain tensions and conflicts between the Bulgarian managers and their German counterparts employed by German enterprises or joint ventures operating in Bulgaria. These conflicts may be induced not only by the language barrier and the social and cultural differences but also by the gap in their technological knowledge and professional skills. Thus, form the point of view of the international personnel management; we may define three models of relations of the three target groups (managers, staff, and labour unions): a model dominated by foreign managers, a model dominated by Bulgarian managers, and a model of equal proportions of foreign and local managers. The interactive relations among the three groups define the responsibilities in the field of personnel management and control. The research proved that the specific internal economic features of the environment have affected in different ways the PM policies of the Bulgarian and the German enterprises and the participation of their personnel in the management of various processes.

The research continued in the analytical fields in order to study the interaction between the PM target groups and the PM tools. According to the adopted model we focused on the planning of personnel demand. The demand is well known to be determined by the actual personnel (number of employees and personnel structure) and the future goals of the enterprise. The demand is defined through its quantitative and structural (qualitative) aspects according to the level of qualification and professional characteristics (Berthel 1991; Hentze/Kammel 2001). This is why the research on the process of planning of personnel demand in the three target groups of enterprises sought answers to the following questions:

- Do all target group enterprises develop personnel demand plans and what is their time span?

- Are there any significant differences of the plans developed by the partnering enterprises in the joint ventures or by the headquarters in Germany and the branches in Bulgaria for the $100 \%$ German enterprises?

- Are there any conflicts between the management and the labour unions on the quantitative and structural (qualitative) aspects of personnel plans?

The results of the empirical study show that a personnel planning is an important part of the strategic corporate management of the German enterprises and the joint ventures. Personnel planning in the enterprises included in these two target groups is based on the "strategy follows people" concept (Friedmann/LeVino 1984; Staehle 1991 b), which confutes the assertion that the personnel management strategies are derived form the overall strategy of the enterprise and are therefore of secondary importance. The planning of personnel demand is not of primary importance for the Bulgarian enterprises although answering the questionnaires they all claimed that it was part of their set of management 
instruments. In some of these enterprises there were contradictions in planning the future demand of personnel predominantly in its quantitative aspect, which led to personnel contraction and redundancies.

The quantity, qualification and time span of personnel demand plans are the basis for the implementation of the personnel potential staff recruitment. The hiring process may be divided into two phases - personnel recruitment and personnel selection. The two phases depend on the specific labour market situation. When the demand of personnel is high (for a certain region or during a certain time period, e.g. season) the recruitment of personnel becomes a priority. When there is a higher supply of workforce priority is given to the selection of personnel. The objective of personnel recruitment is to recruit the necessary number of employees meeting the needs of the enterprise for qualified staff so that the motivation of the staff to correspond to their performance. Thus the study of personnel selection is includes only the external sources. It focuses on the following means of advertising: newspaper advertisements, labour office announcements, contact with universities, personal contacts, and contingent applications. The study was intended to determine and distinguish the role and importance of the various PM instruments as well as to determine the number of candidates competing for one job vacancy announcement and thus to determine whether the selection made was formal or fictitious.

Survey findings showed that the most widely used personnel recruitment method of both the German enterprises and the joint ventures is the „newspaper adds“ followed by ,contacts with universities“. The latter are carried out in the form of long-term co-operation schemes (especially with renowned universities) including internships, practical training, summer practices, and diploma thesis researches on topics suggested by the enterprises. The use of those recruitment schemes shows that the enterprises are trying to solve the problems related to the quality personnel selection and the level of qualification acquired by their employees during their studies. According to the survey the predominant form of personnel recruitment in the Bulgarian enterprises is through labour office announcements followed by newspaper ads and personal contacts.

Personnel selection is intended mainly to single out the most suitable applicants to be employed. The set of applicant selection criteria should guarantee the objectiveness, validity, worthiness and legitimacy of the selection (Chart 1). There are also specific procedures for objective comparison of the job description and the profile of the applicant (Scholz 1993; Zaharieva 2002). The preliminary selection of the applicants is usually performed in the form of personal interviews but the final employment decision is taken on the grounds of a test designed to verify applicants' professional qualification, knowledge, skills and qualities. Sometimes after the preliminary interview the applicant may be hired on probation and to be employed on a regular contract basis after he/she proves that he/she is appropriate for the job. 


\section{Chart 1. Personnel Selection Criteria (According to their frequency of use)}

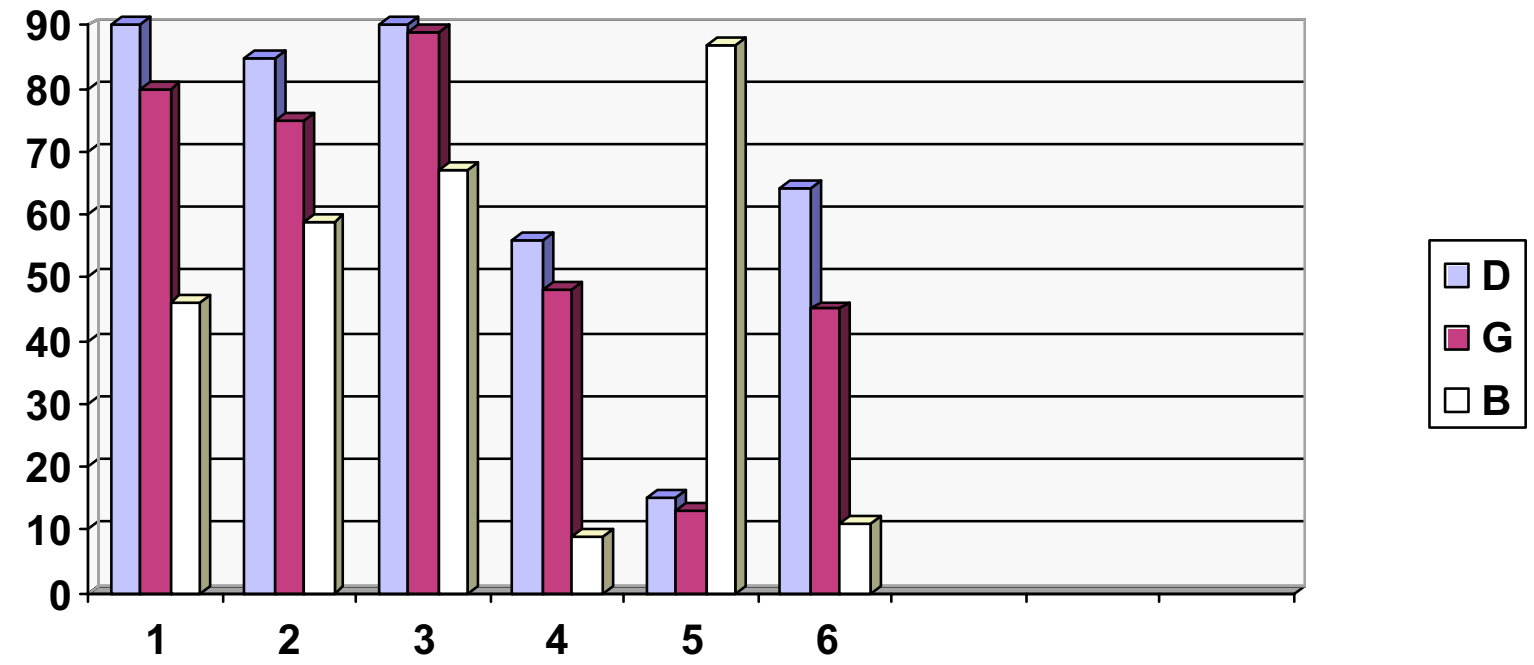

\begin{tabular}{|l|l|l|l|l|l|l|}
\hline Legend & 1. Criterion & \multicolumn{1}{|c}{ 2. Crit. } & 3. Crit. & 4. Crit. & 5. Crit. & 6. Crit. \\
\hline & Age & $\begin{array}{l}\text { Education } \\
\text { level }\end{array}$ & $\begin{array}{l}\text { Language } \\
\text { skills }\end{array}$ & $\begin{array}{l}\text { Communicati } \\
\text { on skills }\end{array}$ & $\begin{array}{l}\text { Length of } \\
\text { service }\end{array}$ & Motivation \\
\hline
\end{tabular}

According to the findings of a study ordered by the Ministry of Labour and Employment the probation period is often used by the Bulgarian enterprises as a means of breaching the Labour Code mainly for low-paid and manual labour. In such cases the employees are usually paid the minimal wage, are often deprived from social security and pension allowances and are fired at the end of the probation period. Thus the employers benefit from the fact that the applicants are often pressed by the lack of employment opportunities and alternative employment ${ }^{4}$.

The research on this set of PM policy instruments was based on the following applicant selection criteria: age, educational level, language skills, communication skills, length of service, applicant's motivation to be employed by the enterprise, because they are the most widely used criteria by the target group enterprises.

However, in applicant selection all the three groups of enterprises give priority to the following criteria: age, educational level, and language skills. Most of the

4 The findings of the research mentioned above prove that this phenomenon is very frequent among the small- and medium-size enterprises (in the sewing industry, services, crafts and trade) and extremely frequent in the agriculture, civil engineering and tourism sectors. To defy this problem the Ministry created a program intended to stimulate the contract-based employment in certain economic sectors and activities by providing tax relies and preferential credits to employers who create permanent jobs paying the social and pension allowances to their employees according to the provisions of our legislation. (Source: Annual Report of the Labor Organization and Social Security Institute at the Ministry of Labor, Sofia, 2002). 
Bulgarian enterprises give priority to the "length of service“ criterion because they prefer experienced specialists. To a certain extent this is also valid for some of the German enterprises but only when they employ personnel for managerial positions. The "motivation" and "communication" skills criteria, which are important for the evaluation of the performance and contribute to the establishing of favourable working environment, are considered by the Bulgarian employers to be of secondary importance in the process of personnel selection. Unlike them both the German entrepreneurs and the joint ventures consider these criteria essential for the process of personnel selection, especially for managerial positions and positions for highly qualified specialists.

Table 2. Results for the empirical research study on „Personnel potential development", (Scaled results, percentage)

\begin{tabular}{|c|c|c|c|}
\hline Criteria/indices & $\begin{array}{l}100 \% \text { German } \\
\text { enterprises }\end{array}$ & $\begin{array}{l}\text { Bulgarian-German } \\
\text { JVs }\end{array}$ & \begin{tabular}{|l|} 
Bulgarian \\
enterprises
\end{tabular} \\
\hline $\begin{array}{l}\text { Related to the development } \\
\text { of personnel potential: } \\
\text {-professional knowledge, } \\
\text {-PC literacy and skills, } \\
\text {-managerial skills, } \\
\text {-language knowledge and } \\
\text { skills }\end{array}$ & $\begin{array}{l}\text { During the service } \\
\text { period these are: } \\
\text {-greatly improved } \\
\text {-greatly improved } \\
\text {-improved } \\
\text {-extremely improved }\end{array}$ & $\begin{array}{l}\text { During the service } \\
\text { period these are: } \\
\text {-improved } \\
\text {-improved } \\
\text {-improved } \\
\text {-extremely improved }\end{array}$ & $\begin{array}{l}\text { During the service } \\
\text { period these are: } \\
\text {-improved } \\
\text {-improved } \\
\text {-less improved } \\
\text {-improved }\end{array}$ \\
\hline $\begin{array}{l}\text { Related to personnel } \\
\text { development methods: } \\
\text { Organisation/participation } \\
\text { in workshops; } \\
\text {-Working meetings/training } \\
\text { participation; } \\
\text {-Case studies; } \\
\text {-Project participation } \\
\text {-Job rotation }\end{array}$ & $\begin{array}{l}\text { Preferred forms in the } \\
\text { range of: } \\
\text { Professional } \\
\text { knowledge, } \\
\text { Language skills; } \\
\text { Communication skills, } \\
\text { Managerial skills; } \\
\text { Professional }\end{array}$ & $\begin{array}{l}\text { Preferred forms in the } \\
\text { range of: } \\
\text { Professional } \\
\text { knowledge, } \\
\text { Language skills; } \\
\text { Communication skills, } \\
\text { Managerial skills; } \\
\text { Professional }\end{array}$ & $\begin{array}{l}\text { Preferred forms in the } \\
\text { range of: } \\
\text { Professional } \\
\text { knowledge, } \\
\text { Language skills; } \\
\quad \text { - } \\
\text { Professional, } \\
\quad \text { - }\end{array}$ \\
\hline $\begin{array}{l}\text { percentage of trainees per } \\
\text { annum (for the period } \\
\text { 1999-2002) in groups: } \\
\text {-managers, } \\
\text {-specialists } \\
\text {-workers }\end{array}$ & $\begin{array}{l}25 \\
43 \\
14\end{array}$ & $\begin{array}{l}31 \\
48 \\
12\end{array}$ & $\begin{array}{l}16 \\
18 \\
7\end{array}$ \\
\hline
\end{tabular}

The development personnel potential and improvement of its qualification are considered prerequisites for the efficiency of personnel management policy. This is why these elements of the PM policy together with the planning of personnel needs determine to a great extent the model of the policy itself. Personnel development and the improvement of its qualification are closely related to the individual professional career plans and the interests of the employees. 
Combined with the efforts of the employers they may serve both as landmarks for the development of the corporate culture and as criteria for career success within the individual enterprise (Damyanov/Zaharieva 1999; Hentze/Kammel 2001).

Personnel development may be evaluated in several aspects: improvement of the professional knowledge and skills; improvement of the computer literacy and communication skills; improvement of the managerial and foreign language knowledge and skills.

From the point of view of the methods applied personnel development may be evaluated using the following criteria: organisation of/participation in workshops; participation in working meetings/training; case studies; participation in projects/project teams; job rotation. The research team sought answers to the following questions:

- Which aspects of personnel development are given priority by the various enterprises?

- Which forms are preferred from the point of view of personnel development methods used?

- Which employee categories are considered more important - the executive staff the specialists or the blue-collar workers?

The empirical study provided the following (Table 2.) results:

- in the groups of the German enterprises and the joint ventures during their service the employees greatly improve their professional and language knowledge and skills while those employed by Bulgarian entrepreneurs are not guaranteed such opportunities;

- considering the forms and methods for development of personnel potential the German enterprises and the joint ventures apply all forms stated above while their Bulgarian counterparts prefer the organised forms of specialised training provided either on site or in specialised training centres.

Personnel redundancy is an important factor for the PM policy. It may be due to personal reasons or the circumstances related to the specific market situation, which is shaped by the level of economical stability in the country. The empirical study proved that in both the German enterprises and the joint ventures the economical reasons for personnel redundancy do not exist. Unlike them the Bulgarian enterprises often explain the redundancy with the unfavourable business environment in the country demanding for personnel cuts and reduction of the volume of production. The latter are most often related not to the privatisation process but rather to some temporary market difficulties faced by the enterprises. Here we should point out that there was a wave of large-scale redundancy in most Bulgarian enterprises in mid-90s, when the economic reforms in the country called for complete restructuring of our economy. 
For the last few years there was a drastic redundancy in the enterprises, which survived the economic reforms. The reasons behind the high level of manpower fluctuation are the low or irregular remuneration, bad working conditions or poor workplace climate.

According to the theories concerning the efficiency of labour employment is based on the "payment relevant to the workload" principle (Arx 1995, Gross/Haberman 2002), in which the payment scheme corresponds to the system of evaluation and grading of labour (Wunderer 1999; Stephenson 2002). In general the nature of labour may be defined by the character and methods of production or by the specifics of services provided. However, it also depends on the division of labour and production specialisation. The organisation of labour in the three target groups of enterprises was studied and compared using the following three criteria:

- The differences in the division of labour according to the number/accumulation of production operations in similar productions or activities - Criterion 1.;

- The level of communications (two-way, constant flow of information) Criterion 2.;

- The number of interruptions of the production process (due to both external and internal reasons) - Criterion 3.

The comparative analysis shows that there are no significant differences in the organisation of labour in the three target groups of enterprises. The existing discrepancies according to Criterion 1 are due to the differences of technological equipment or the specifics of technologies employed. Therefore we may conclude that the differences in labour organisation that existed at the beginning of the structural economic changes are already obliterated. Therefore there are no essential differences in the organisation of labour, arising from the different models of PM policy employed by in the Bulgarian and the German enterprises. The free-market principles and mechanisms of production efficiency have become key factors for the formation of labour relations in the Bulgarian enterprises, which compete not only with their German rivals but also with all other enterprises operating in Bulgaria.

The Stimulation policy being an intrinsic part of the organisation of labour proved to be of crucial importance to the research. The equivalent characteristics of labour relations determine the characteristic s of the remuneration system and shape the PM policy employed by the enterprise. Here comes the problem of the nature and form of remuneration (Shopov 1997). Since the remuneration may be material and non-material the researchers sought the answer to the question which form is considered more important by the employees of Bulgarian and German enterprises? Here we considered the fact that a great number of material stimuli have some immaterial components. 
Table 3. Results for the empirical research study in the PM tools field "Stimulation policy“

\begin{tabular}{|c|c|c|c|}
\hline Criteria/indices & $\begin{array}{l}100 \% \text { German } \\
\text { enterprises }\end{array}$ & $\begin{array}{l}\text { Bulgarian- } \\
\text { German JV }\end{array}$ & $\begin{array}{l}\text { Bulgarian } \\
\text { enterprises }\end{array}$ \\
\hline $\begin{array}{l}\text { Preferred criteria in the field of } \\
\text { remuneration: }\end{array}$ & $\begin{array}{l}\text { Differentiation of the } \\
\text { criteria according to } \\
\text { their importance: }\end{array}$ & & \\
\hline -basic salary & Main criterion & Main criterion & Main criterion \\
\hline $\begin{array}{l}\text {-qualification/grade, job } \\
\text { complexity }\end{array}$ & Additional criterion & Additional criterion & Additional criterion \\
\hline -hierarchical position benefits & Main criterion & Main criterion & Main criterion \\
\hline -turnover/profit share & Main criterion & Additional criterion & Additional criterion \\
\hline -safety of labour & Main criterion & Main criterion & Main criterion \\
\hline -additional workload & Main criterion & Additional criterion & Additional criterion \\
\hline -night shifts & Main criterion & Main criterion & Additional criterion \\
\hline Forms of remuneration: & & & \\
\hline -material stimulation, incl. & Strongly preferred & Strongly preferred & Strongly preferred \\
\hline -financial, & Preferred & Strongly preferred & Preferred \\
\hline -non-financial & Not preferred & Preferred & Strongly preferred \\
\hline -immaterial stimulation & Strongly preferred & Preferred & Not preferred \\
\hline
\end{tabular}

This is why the analysis was based on the following principles applied in the development of simulation policy (Hentze/Kammel 2001):

- Reciprocating of the remuneration with the individual performance resulting in greater personal satisfaction from the achieved results;

- Interlocking of the personal and collective interests observing the correlation between payment and remuneration;

- Formation of relations based on labour stimulation, which are compliant with the aims of the enterprise and consolidate its corporate culture.

The above principles determine the main and additional criteria used for the comparative analysis of the various models of stimulation policy (Table 3.)

Since no significant differences in the methods of basic salary formation were found, the comparative analysis was to find the answer of the following question: What are the reasons for the substantial differences between the three target groups of enterprises in the field of the formation of benefits. Indeed, due to the harmonisation of the Bulgarian labour legislation the formation of benefits (especially those for night shifts, additional workload, etc.) is uniform with those of the EC countries. Here the most important thing is to determine whether the criteria are main or additional in their nature. For example the reciprocating of the benefits with the performance of the enterprise would be a characteristic element of the stimulation system showing the relation between the collective and the personal interest. 
The policies of the German enterprises rely strongly on this characteristic and in them the strong personal contribution to the company's performance is reflected by the additional remuneration of every employee. Moreover, the German enterprises apply various other stimuli (for quality of performance, innovativeness, rationalisation of labour, etc.) while their Bulgarian counterparts don't. From the point of view of the forms of remuneration the empirical study found out that in the German enterprises and the joint ventures the immaterial stimulation forms are applied more often and have a positive effect on employee satisfaction while the Bulgarian enterprises prefer the immaterial stimuli. The inquiry data also proved that the level of payment in the German enterprises and in most of the joint ventures is higher than that of the Bulgarian enterprises. This is why the question about the correlation remuneration-satisfaction-motivation (i.e. whether the better remuneration in the German enterprises inevitably leads to growth of motivation and hence - better performance) is of primary importance.

The analysis of the last instrument - "Stimulation policy" - of the analytical field of PM instruments proved that all the three target groups of enterprises subjected to the research form their policies in direct relation to their performance, achieved as a result of the adoption of certain labour evaluation criteria. This proves that the remains of the old principle of equal payment, which was used during the socialist era, have been overcome by the Bulgarian enterprises and that they have adopted the free-market principles of labour evaluation in their PM policies.

On the grounds of the research carried out in the field of PM instruments (including planning of personnel needs, personnel recruitment, labour organisation, development of employee potential, personnel stimulation and redundancy) we may draw the following conclusions:

- There are no significant differences in the models of interaction between PM groups and PM instruments in all the three target groups of enterprises operating in Bulgaria;

- A substantial part of the Bulgarian enterprises included in the research have achieved positive results in modelling the above-mentioned interaction due to internal corporate transformations caused by the adoption of freemarket principles as well as the legislative and economic reforms undertaken in the country in recent years;

- Joint ventures successfully transfer managerial expertise from the German to the Bulgarian partners and thus naturally adopt new management techniques and adapt them to the specifics of our economy and value system. Thus they diversify our business practice and create favourable conditions for multiplication of the positive results of the specific exchange of culture and technologies between the Bulgarian and German businesses.

The above arguments on the differences between the PM target groups and PM instruments in the Bulgarian and German enterprises operating in the markedly 
dynamic business environment of Bulgarian economy may be summarised in the following comments:

The policy of the $100 \%$-German enterprises operating in Bulgaria is based on the specific market conditions that allow them to benefit from the business environment in the country. To do this they use their decision-making competencies including those related to personnel management. Thus the human resource management of these enterprises complies with the requirements of the international management.

In the Bulgarian-German joint ventures (JV) the partners develop their relations of co-operation and integration and thus improve the competitiveness of their businesses in comparison with the other enterprises in Bulgaria. They benefit from the synergetic effects of their co-operation in the fields of both resource pooling and know-how transfer and develop interactive models of personal management policy. Personnel management of these enterprises is based on the implementation of dualistic strategies.

The comparative analysis proved that the Bulgarian enterprises should face the challenges of the interactive approach to model the interaction between PM target groups and PM instruments for personnel management. Despite the fact that they must operate under the pressure of the market principles shaping the business environment in Bulgaria they nevertheless have certain traditions in the field of personnel management policy. Hence the mechanic copying of the foreign models in that field could not guarantee their success. The have to scrutinise the foreign experience and adapt it to the specific mentality of our nation and thus to achieve the so called cultural transfusion in the field of personnel management, which may be considered an act of internationalisation and harmonisation of our standards with the European ones.

\section{References}

Annual Report of the Labor Organization and Social Security. Institute at the Ministry of Labor (ed.), (2002), Sofia.

Arx, K.J.(1995): Das Wertschöpfungs- Center-Konzept als Strukturansatz zur unternehmerischen Gestaltung der Personalarbeit. In: Wunderer, R. /Kuhn, T. (Hrsg.): Innovatives Personalmanagement : Theorie und Praxis unternehmerischer Personalarbeit, Neuwied/Kriftel/Berlin, 423-441.

Berthel, J.(1991): Personal Management, Grundzüge für Konzeptionen betrieblicher Personalarbeit. 3. Auflage, Stuttgart, 152-176.

Bojadziew, D.(1997): Human Resource Management. Sofia: University Press "Economic, 93.

Bulgarische National Bank, Berichte, Sofia, Periode 1999-2002.

Damyanov, A./G.Zaharieva (1999): Personal Management - national and international aspects. Academic Publ.” Tsenov". Svishtov, 254.

Das Arbeitsgesetzbuch: Dokument Nr.VII.1.1990; Verordnung des Ministerrates Nr.49/1991. 
F.A.Z.-Institut: Jahrbuch 2001/2002, Mittel- Osteuropa Perspektiven,Verl. Rödl\&Partner, Frankfurt am Main, 57-65.

Friedmann, S./Le Vino, T.(1984): Strategic Appreisal and Development at GE Company. In: Strategic Human Ressource Management, hrsg. C. Formburn, New York, 183-201.

Gross, St,/S. Haberman (2002): Total compensation in a ression: HR priorities shift according to new surwey Analysis. Employee Benefits Journal , Mar., Vol. 27 Issue 1.

Hentze, J.(1989): Personalwirtschaftslehre, Bd.1, 4. Aufl. , Bern - Stuttgart.

Hentze, J.; Kammel A. (2001): Personalwirtschaftslehre - 1, 7. Auflage. Haupt UTB, Verlag Paul Haupt, Bern-Stuttgart-Wien, 101-122.

Holtbrügge, D./Sulus, A.(1992): Ökonomische Perspektiven der Gemeinschaft Unabhängiger Staaten. In: Osteuropa, Nr. 42. Jg.9, 727-741.

Hristova, G. (1996): Human Resource Management. Varna: Princes Publ., 283.

Peters, T.J./Waterman, R.H.(1984): Auf der Suche nach Spitzenleistungen, Landsberg a. L.

Scholz, C. (1993): Personalmanagement - Informationsorientierte und verhaltenswissenschaftliche Grundlagen. 3. Aufl., München.

Schuster, F.(1996): The Schuster - Report: The Proven Connection between People and Profit. N.Y., 152-167.

Shopov D. (1997): Motivation and payment strategies. Sofia: University Press "Economic", 258260.

Staehle, W.H.: Simultane Strategie- und Personalentwicklung, in: ZfP, 5. Jg., Nr. 1., 1991, 5-12.

Staehle, W.H. (1991): Management. Eine Verhaltenswissenschaftliche Perspektive. 6. Aufl. München.

Stefanov, W. (1991): Personal Management. Sofia: University Press "Economic", 45-51.

Stephenson, S. (2002): Motivating Your Staff, in: Food Service Director,1/15, 92.

UNECE (ed) (2000): East-West Joint Ventures. Economic, Business, Genf.

Wunderer, R. (1999): Unternehmerisches Personalcontrolling: Evaluation der Wertschöpfung im Personalmanagement, Neuwied.

Zaharieva G. (2002): Bulgarian practice for motivation of personal, in: National Economy Archive. Academic Publ. "Tsenov". Svishtov, Vol.3, 37-39. 